\title{
Reclassification of Streptomyces flavidofuscus as a synonym of Nocardiopsis dassonvillei subsp. dassonvillei
}

Correspondence

Tomohiko Tamura

tamura-tomohiko@nite.go.jp

\author{
Tomohiko Tamura, Yuumi Ishida, Misa Otoguro, Kazunori Hatano \\ and Ken-ichiro Suzuki
}

\author{
NITE Biological Resource Center (NBRC), National Institute of Technology and Evaluation, 2-5-8 \\ Kazusakamatari, Kisarazu, Chiba 292-0818, Japan
}

\begin{abstract}
During the course of quality control studies of the collection of the NITE Biological Resource Center (NBRC), phylogenetic analysis based on 16S rRNA gene sequences of actinomycetes revealed that Streptomyces flavidofuscus NBRC $15404^{\top}$ formed a cluster with Nocardiopsis dassonvillei and Nocardiopsis synnemataformans. Strain NBRC $15404^{\top}$ contained mesodiaminopimelic acid as a cell-wall diamino acid and DNA-DNA hybridization studies also showed that S. flavidofuscus NBRC $15404^{\top}$ was a close relative of $N$. dassonvillei subsp. dassonvillei NBRC $14626^{\top}$. Based on chemotaxonomic, phenotypic and genetic analysis of the type strain, Streptomyces flavidofuscus should be reclassified as a later heterotypic synonym of Nocardiopsis dassonvillei subsp. dassonvillei.
\end{abstract}

The genus Streptomyces is the largest genus of actinomycetes, containing more than 500 species with validly published names. They are characterized phenotypically by morphology and the presence of a type I cell wall. The genus Nocardiopsis was established by Meyer (1976) on the basis of morphological characteristics and the presence of cell-wall type III/C. The genus currently comprises more than 20 species. Members of this taxon are characterized chemotaxonomically by possessing phosphatidylcholine and phosphatidylmethylethanolamine as diagnostic phospholipids, menaquinone (MK)-10 with variable degrees of saturation (Collins et al., 1977), iso-, anteiso- and 10methyl-branched fatty acids (fatty acid type 3d sensu Kroppenstedt, 1985) and meso-diaminopimelic acid (meso$\mathrm{A}_{2} \mathrm{pm}$ ). They lack diagnostic sugars (cell-wall chemotype III/C sensu Lechevalier \& Lechevalier, 1970) and mycolic acids. They contain the acetyl type of muramic acid and have a G+C content of 64-69 mol\% (Grund \& Kroppenstedt, 1990).

During the course of quality control of the collection of the NITE Biological Resource Center (NBRC), it was revealed that NBRC $15404^{\mathrm{T}}$, the type strain of Streptomyces flavidofuscus (Gause et al., 1983), was classified phylogenetically within the genus Nocardiopsis. Therefore, the taxonomic position of $S$. flavidofuscus was studied further.

PCR amplification and 16S rRNA gene sequencing and phylogenetic analysis were performed as described previously (Tamura \& Hatano, 2001). $16 \mathrm{~S}$ rRNA gene

The GenBank/EMBL/DDBJ accession number for the 16S rRNA gene sequence of strain NBRC $15404^{\top}$ is $\mathrm{AB} 184655$. sequence analysis revealed that S. flavidofuscus NBRC $15404^{\mathrm{T}}$ was incorporated in a monophyletic cluster with members of the genus Nocardiopsis (Fig. 1). The binary similarity value of the $16 \mathrm{~S}$ rRNA gene sequence of $S$. flavidofuscus $\mathrm{NBRC} 15404^{\mathrm{T}}$ was $99.5 \%$ with Nocardiopsis dassonvillei subsp. dassonvillei DSM $43111^{\mathrm{T}}, 99.7 \%$ with $N$. dassonvillei subsp. albirubida NBRC $13392^{\mathrm{T}}$ and $99.8 \%$ with Nocardiopsis synnemataformans IMMIB D-1215 ${ }^{\mathrm{T}}$. The sequence of S. flavidofuscus NBRC $15404^{\mathrm{T}}$ was $100 \%$ similar to the sequence submitted to GenBank as AY999914, derived from S. flavidofuscus NRRL B-16366 ${ }^{\mathrm{T}}$. This means the phylogenetic position of the type strain of S. flavidofuscus has been confirmed by using multiple strains preserved in different culture collections.

Cell-wall amino acids, whole-cell sugars, cellular fatty acids, isoprenoid quinones and DNA base composition were analysed as described previously (Tamura et al., 1994). Freeze-dried cells for chemotaxonomic analyses were prepared from cultures grown in yeast extract-glucose broth [containing $\left(1^{-1}\right) 10 \mathrm{~g}$ yeast extract and $10 \mathrm{~g} \mathrm{D}$ glucose, $\mathrm{pH}$ 7.2] on a rotary shaker at $28{ }^{\circ} \mathrm{C}$ for 3 days. The predominant menaquinones were $\mathrm{MK}-10\left(\mathrm{H}_{6}\right)$ and $\mathrm{MK}$ $10\left(\mathrm{H}_{8}\right)$, with MK-10 $\left(\mathrm{H}_{4}\right)$, MK-9 $\left(\mathrm{H}_{6}\right)$ and MK-9 $\left(\mathrm{H}_{8}\right)$ as minor components. The strain contained meso- $\mathrm{A}_{2} \mathrm{pm}$, alanine and glutamic acid in the cell wall and ribose and mannose as whole-cell sugars. The major cellular fatty acids were iso- $\mathrm{C}_{16: 0}(50 \%), 10$-methyl $\mathrm{C}_{18: 0}(12 \%)$ and anteiso$\mathrm{C}_{17: 0}(10 \%)$. The DNA G $+\mathrm{C}$ content was $71 \mathrm{~mol} \%$. The chemotaxonomic characteristics of $S$. flavidofuscus NBRC $15404^{\mathrm{T}}$ were consistent with those of the genus Nocardiopsis. 


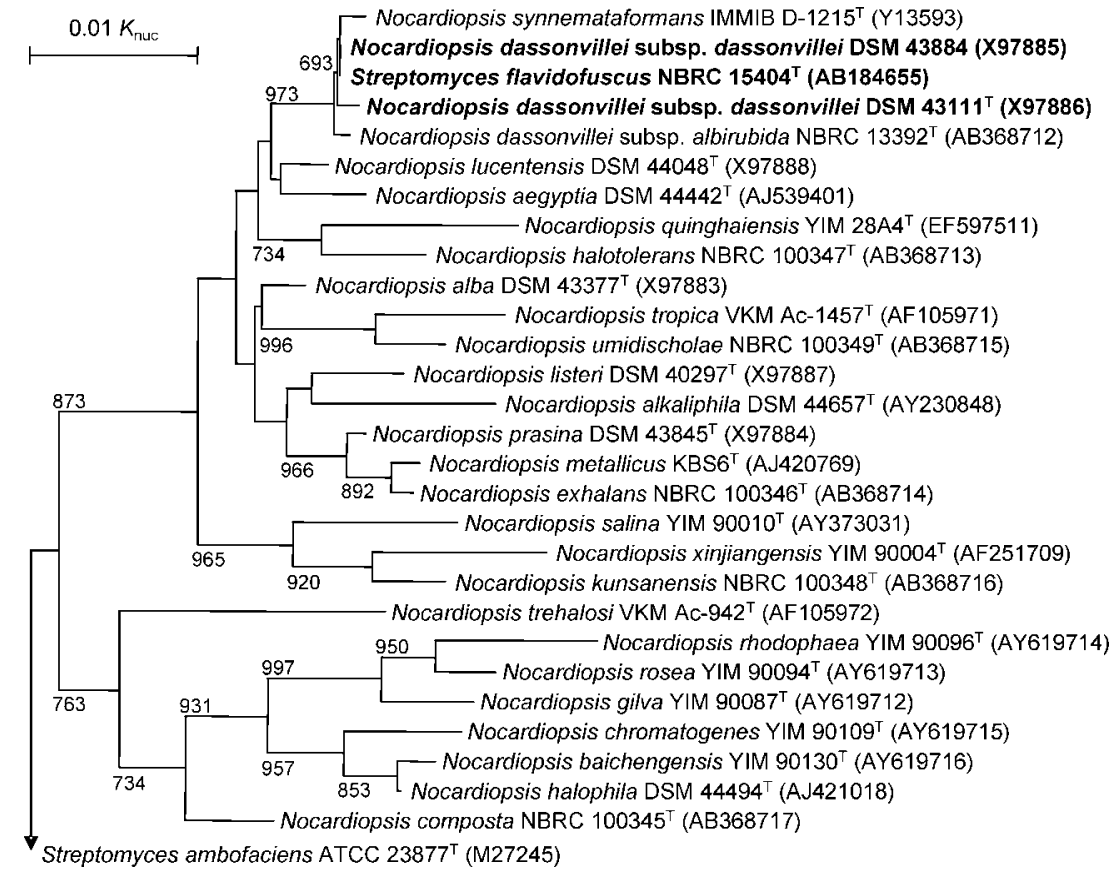

Fig. 1. Phylogenetic tree derived from the 16S rRNA gene sequences of $S$. flavidofuscus NBRC $15404^{\top}$ and members of the genus Nocardiopsis. N. dassonvillei subsp. dassonvillei DSM 43884 is the type strain of Nocardiopsis antarctica. The tree was constructed using the neighbour-joining method (Saitou \& Nei, 1987). The sequence of Streptomyces ambofaciens ATCC $23877^{\top}$ was used as an outgroup. Bar, $0.01 K_{\text {nuc }}$ in nucleotide sequences. Numbers on branches are confidence limits estimated by bootstrap analysis with 1000 replicates (only values above 500 are presented).
The microplate hybridization method developed by Ezaki et al. $(1988,1989)$ was used for the determination of DNADNA relatedness. The relatedness values of $S$. flavidofuscus NBRC $15404^{\mathrm{T}}$ to $N$. dassonvillei subsp. dassonvillei NBRC $14626^{\mathrm{T}}, N$. dassonvillei subsp. albirubida NBRC $13392^{\mathrm{T}}$ and N. synnemataformans NBRC $102581^{\mathrm{T}}$ were $81-87,55-79$ and 55-63\%, respectively. N. dassonvillei subsp. albirubida NBRC $13392^{\mathrm{T}}$ exhibited high relatedness $(59-73 \%)$ to $N$. dassonvillei subsp. dassonvillei NBRC $14626^{\mathrm{T}}$, as reported by Evtushenko et al. (2000). Further, N. synnemataformans NBRC $102581^{\mathrm{T}}$ exhibited $43-61 \%$ relatedness to $N$. dassonvillei subsp. dassonvillei NBRC $14626^{\mathrm{T}}$ and $53-79 \%$ relatedness to $N$. dassonvillei subsp. albirubida NBRC $13392^{\mathrm{T}}$. These species and subspecies are genetically closely related to each other.

The cultural characteristics of $S$. flavidofuscus NBRC $15404^{\mathrm{T}}$ were similar to those of $N$. dassonvillei subsp. dassonvillei $\mathrm{NBRC} 14626^{\mathrm{T}}$, i.e. they produced a pale-brown soluble pigment in NBRC medium 229 [containing $\left(\mathrm{l}^{-1}\right)$ $5 \mathrm{~g}$ yeast extract, $50 \mathrm{~g}$ glycerol, $1 \mathrm{~g} \mathrm{CaCO}_{3}$ and $20 \mathrm{~g}$ agar, $\mathrm{pH}$ 7.3; NBRC catalogue] and developed colourless to palebrown colonies on NBRC medium 229, yeast extract-starch agar $\left[\left(1^{-1}\right) 2 \mathrm{~g}\right.$ yeast extract, $10 \mathrm{~g}$ soluble starch and $18 \mathrm{~g}$ agar, $\mathrm{pH}$ 7.3], Bennett's maltose agar $\left[\left(\mathrm{l}^{-1}\right) 1 \mathrm{~g}\right.$ yeast extract, $1 \mathrm{~g}$ beef extract, $2 \mathrm{~g} \mathrm{NZ}$ amine type A, $10 \mathrm{~g}$ maltose and $20 \mathrm{~g}$ agar, $\mathrm{pH}$ 7.3] and yeast extract-malt extract agar (ISP 2; Shirling \& Gottlieb, 1966). However, S. flavidofuscus NBRC $15404^{\mathrm{T}}$ differed from $N$. dassonvillei subsp. dassonvillei NBRC $14626^{\mathrm{T}}$ with regard to the production of a pale-brown soluble pigment on yeast extract-starch, Bennett's maltose and yeast extract-malt extract agars.

The results of the present study revealed that strain NBRC $15404^{\mathrm{T}}$, the type strain of S. flavidofuscus, was identified as a strain of $N$. dassonvillei subsp. dassonvillei. The identity of the 16S rRNA gene sequence of strain NBRC $15404^{\mathrm{T}}$ to that of NRRL B- $16366^{\mathrm{T}}$ strongly suggests that this is not merely true for this particular strain but is generalized to the concept of the species. Therefore, the name Streptomyces flavidofuscus Preobrazhenskaya 1986 should be treated as a later heterotypic synonym of Nocardiopsis dassonvillei subsp. dassonvillei (Brocq-Rousseau 1904) Meyer 1976.

\section{References}

Collins, M. D., Pirouz, T., Goodfellow, M. \& Minnikin, D. E. (1977). Distribution of menaquinones in actinomycetes and corynebacteria. $J$ Gen Microbiol 100, 221-230.

Evtushenko, L. I., Taran, V. V., Akimov, V. N., Kroppenstedt, R. M., Tiedje, J. M. \& Stackebrandt, E. (2000). Nocardiopsis tropica sp. nov., Nocardiopsis trehalosi sp. nov., nom. rev. and Nocardiopsis dassonvillei subsp. albirubida subsp. nov., comb. nov. Int J Syst Evol Microbiol 50, 73-81.

Ezaki, T., Hashimoto, Y., Takeuchi, N., Yamamoto, H., Liu, S.-L., Miura, H., Matsui, K. \& Yabuuchi, E. (1988). Simple genetic identification method of viridans group streptococci by colorimetric dot hybridization and quantitative fluorometric hybridization in microdilution wells. J Clin Microbiol 26, 1708-1713.

Ezaki, T., Hashimoto, Y. \& Yabuuchi, E. (1989). Fluorometric deoxyribonucleic acid-deoxyribonucleic acid hybridization in microdilution wells as an alternative to membrane filter hybridization in which radioisotopes are used to determine genetic relatedness among bacterial strains. Int J Syst Bacteriol 39, 224-229.

Gause, G. F., Preobrazhenskaya, T. P., Sveshnikova, M. A., Terekhova, L. P. \& Maximova, T. S. (1983). A Guide for the Determination of Actinomycetes. Genera Streptomyces, Streptoverticillium and Chainia. Moscow: Nauka (in Russian).

Grund, E. \& Kroppenstedt, R. M. (1990). Chemotaxonomy and numerical taxonomy of the genus Nocardiopsis Meyer 1976. Int J Syst Bacteriol 40, 5-11. 
Kroppenstedt, R. M. (1985). Fatty acid and menaquinone analysis of actinomycetes and related organisms. In Chemical Methods in Bacterial Systematics, pp. 173-199. Edited by M. Goodfellow \& D. E. Minnikin. London: Academic Press.

Lechevalier, H. G. \& Lechevalier, M. P. (1970). A critical evaluation of the genera of aerobic actinomycetes. In The Actinomycetales, pp. 393405. Edited by H. Prauser. Jena: Gustav Fischer.

Meyer, J. (1976). Nocardiopsis, a new genus of the order Actinomycetales. Int J Syst Bacteriol 26, 487-493.

Saitou, N. \& Nei, M. (1987). The neighbor-joining method: a new method for reconstructing phylogenetic trees. Mol Biol Evol 4, $406-425$.
Shirling, E. B. \& Gottlieb, D. (1966). Methods for characterization of Streptomyces species. Int J Syst Bacteriol 16, 313-340.

Tamura, T. \& Hatano, K. (2001). Phylogenetic analysis of the genus Actinoplanes and transfer of Actinoplanes minutisporangius Ruan et al. 1986 and 'Actinoplanes aurantiacus' to Cryptosporangium minutisporangium comb. nov. and Cryptosporangium aurantiacum sp. nov. Int $J$ Syst Evol Microbiol 51, 2119-2125.

Tamura, T., Nakagaito, Y., Nishii, T., Hasegawa, T., Stackebrandt, E. \& Yokota, A. (1994). A new genus of the order Actinomycetales, Couchioplanes gen. nov., with descriptions of Couchioplanes caeruleus (Horan and Brodsky 1986) comb. nov. and Couchioplanes caeruleus subsp. azureus subsp. nov. Int J Syst Bacteriol 44, 193-203. 